\title{
COINS AND MESSAGES: \\ AUDIENCE TARGETING ON COINS OF DIFFERENT \\ DENOMINATIONS?
}

By

OLIVIER HEKSTER

Some Romans were aware of the images and legends on their coins. Passages from various literary texts make this clear. The examples are well known. The Gospel of Matthew, for instance, tells us how:

"They brought him a denarius, and he said to them, 'whose portrait is this? and whose inscription?' and they said to him: 'Caesar's'. Then he said to them, 'Give to Caesar what is Caesar's'."

Sceptics could still argue that this passage actually shows a lack of awareness of images on coins from the part of the public, as the emperor's portrait and inscription needed pointing out. Arrian, however, in a famous passage, goes further and explicitly connects value judgements on individual emperors with their particular coins. He takes it entirely for granted that people were aware of which emperor was depicted on which coin:

"The stamps with which a man comes imprinted on his disposition [are] like the stamps we look for on coins too: if we find them we accept their value, if we don't, we chuck them out. 'Whose stamp does this serterce bear? Trajan's? Take it. Nero's? Chuck it out, it will not pass, it is rotten." (Arrian, Discourses of Epictetus 4.5.15-17)

Even if people did not 'chuck out' the coins of 'evil emperors' (and they probably did not), the emphasis on awareness of the individuals depicted on coins is striking. It seems to imply more than mere economic awareness of the

\footnotetext{
* This paper has been greatly improved by the critical comments of Chris Howgego and Cathy King, who kindly read an earlier draft. They saved me from many mistakes, but should not be held responsible for any remaining blunders, nor for the opinions that are ventilated. My gratitude, also, to the participants of the workshop, especially Werner Eck and Richard Talbert. But most thanks should go to Thijs Goverde, who pointed out to me the possible relevance of 'brands' and 'marketing' as a modern parallel for my ideas on the Roman world.

${ }^{1}$ Matthew 22.21; Cf. Mark 12.17, Luke 20.24.
} 
value of coins from the part of the authors. ${ }^{2}$ People saw the images on coins and reacted to them in a variety of ways. Hence, for instance, Hadrian's putting down of the Bar Kokhba revolt ( $\mathrm{AD}$ 132-5), was followed by a rabbinical prohibition for Jews to use coins of that emperor. His coins - though economically of course still valid modes of payment - had become tainted. ${ }^{3}$

Coins were an important medium in the Roman world. Were they consciously employed to reach specific audiences? This question is, of course, a central one to our understanding of Roman 'ideology' and its dissemination. Unsurprisingly, many scholars have already grappled with it, and it is thus with some trepidation that I would like to suggest a way in which the question could be answered. ${ }^{4}$ That is, one might want to look whether there was a diversification of messages between coins of different denominations. If so, one could argue that there was awareness amongst those who designed coins that different denominations could target different groups of audiences. In a way, this addresses an important problem formulated by A.H.M. Jones. Almost 50 years ago, he heavily criticized the notion of coins as 'propaganda', and noted: 'It would be a matter of some interest if numismatists could try to determine, on internal evidence, within the general probabilities of the situation, at what classes the propaganda on the coins was directed' ${ }^{5}$ If different denominations sent out different messages to different audiences, Jones' challenge may have been met.

\footnotetext{
${ }^{2}$ Cf. Arrian, Discourses of Epictetus 3.3.3; Artemidorus, Oneirocritica 4.31; Dio Cassius 78.16.5; CTh 9.22, and Statius, Silvae 4.9.22 on a gift, which was only worth plus minus asse Gaiano - though this may refer to Claudius' invalidation of Gaius' coins: Dio Cassius 60.22.3; A.A.Barrett, 'The Invalidation of Currency in the Roman Empire: The Claudian Demonetization of Caligula's Aes', in: G. Paul \& M. Ierardi, eds., Roman Coins and Public Life under the Empire. E. Togo Salmon Papers II (Ann Arbor 1999), 83-93. Perhaps also of relevance is the importance of destroying hated predecessors' coinage: Dio Cassius, 60.22.3; 78.12.6. Cf. Dio Cassius 64.6; G.A. Crump, 'Coinage and imperial thought', in: J.W.Eadie \& J. Ober, eds., The Craft of the Ancient Historian. Essays in Honour of Chester C. Starr (Lanham 1985), 425-441; 430-431.

${ }^{3}$ Similarly, the fact that the rebels issued their own coinage, with clear symbolic messages, shows how value-laden coinage can be. Coinage was used as a medium to broadcast the rebels' unity against the messages that Roman coins put forward; L. Mildenberg, The Coinage of the Bar Kokhba War (Frankfurt am Main 1984). Cf. W. Eck, 'The Bar Kokhba revolt: the Roman point of view', Journal of Roman Studies 89 (1999), 76-89.

${ }^{4}$ I would like to make clear from the start that this article deals solely with imperial coinage. I am quite aware that Roman provincial coinage followed and entirely different model. For analysing central ideology, one must, however look to imperial coinage.

5 A.H.M. Jones, 'Numismatics and History', in: R.A.G. Carson \& C.H.V. Sutherland, eds., Numismatics and History. Essays in Roman Coinage Presented to Harold Mattingly (London 1956), $13-33 ; 15$.
} 
Many have, as said, discussed these matters, and significant contributions by, amongst others, Barbara Levick, Michael Crawford, Andrew Wallace-Hadrill, Cathy King, Peter Lummel and Carlos Noreña have paved the way. ${ }^{6}$ An important recent article by Andrew Meadows and Jonathan Williams has put forward the notion of 'monumentality' to understand coin types of the late Republic. They argue that 'propaganda' is not quite the right term, since the coins did not try to persuade but to remind people of certain aspects or events. Meadows and Williams may very well be right, but they never deny some sort of 'communication of a message'. This article aims to look at whether such messages (whether they are called 'propaganda' or not) may have been consciously directed at specific audiences.' Also still important to the present paper are Sutherland's influential Coinage in Roman Imperial Policy and his later The Emperor and the Coinage, which still dominate debates. ${ }^{8}$ Sutherland - arguing strongly against Jones' minimalist views on the purpose of coinage - showed after extensive analysis of a wide range of coins that the contents of coins, in the long range, remained more or less the same, independent of the value of the coins in question.

But recently, in an interesting article, William Metcalf has tried to show differentiation of messages in coins of different denominations. Using the figure of Liberalitas as an example, he argues that she was depicted differently on different types of coins. Precious metal coins, in his analysis, depicted Liberalitas as a personification, whereas aes coins show a Liberalitas scene. He concluded from this that:

\footnotetext{
${ }^{6}$ B. Levick, 'Propaganda and the Imperial Coinage', Antichthon 16 (1982), 104-116; M. Crawford, 'Roman Imperial Coin Types and the Formation of Public Opinion', in: C. N. Brooke, et al., eds., Studies in Numismatic Method Presented to Philip Grierson (Cambridge 1983), 47-64; A. WallaceHadrill, 'Image and Authority in the Coinage of Augustus', Journal of Roman Studies 67 (1986), 6687; C. Howgego, Ancient history from coins (London 1995); C. King, 'Roman Portraiture: Images of Power', in: Paul/lerardi 1999, op. cit. (n. 2), 123-136; P. Lummel, 'Zielgruppen' römischer Staatskunst. Die Münzen der Kaiser Augustus bis Trajan und die trajanischen Staatsreliefs (München 1991); C.F.Noreña, 'The Communication of the Emperor's Virtues', Journal of Roman Studies 91 (2001), 146-168. For a good overview of the discussion: B. Levick, 'Messages on the Roman Coinage: Types and Inscriptions', in: Paul/lerardi 1999, op. cit. (n. 2), 41-60.

${ }^{7}$ A. Meadows \& J. Williams, 'Moneta and the Monuments: Coinage and Politics in Republican Rome', Joumal of Roman Studies 91 (2001), 27-49. One needs to remember that the situation in the Empire was noticeably different from the late Republic, with one man in power rather than several families fighting for prestige.

${ }^{8}$ C. H. V. Sutherland, Coinage in Roman Imperial Policy (London 1951); idem, The Emperor and the Coinage. Julio-Claudian Studies (London 1976).
} 
"The precious-metal coins, with their limited but longer circulation ... were confined ... to circulation among the higher classes of ancient society, and memorialized the emperor's liberalitas itself. The aes coinage, with its primarily Italian and indeed urban circulation, largely among the lower classes, could quite properly focus on the event that led to the circulation of the money in the first place."

Metcalf's differentiation in types of audiences is an important one, and, I believe, essentially right. ${ }^{10}$ This is not to say that the lower strata of society would never see precious-metal coins, or that every individual in the Roman Empire would fit into only one 'target group'. Yet, though the boundaries between different audiences must have been somewhat blurred, it seems probable that one could at least distinguish between primary and secondary types of audience. Metcalf's argument, however, fails to take into account a crucial point. Centrally issued precious-metal coins in the early empire were much smaller than bronzes, quadrantes aside, and the difference in size may well have been the important factor in deciding for a personification or a more space-taking scene. Audience targeting will have been, at best, a lesser consideration.

In fact, it appears that any search for overarching differences between coins of different denominations throughout the entire Principate, is doomed to fail. Legend types like ANNONA or CERES, which one would expect to be more relevant for people in need of food, appear almost exclusively in lower denomination on coinage from the reigns of Claudius, Nero, Galba, Vitellius, Domitian and Nerva, but they are prominently displayed on all types of coins (including aurei) in the reigns of Vespasian, Titus, Trajan and Hadrian. ${ }^{11}$ Even

\footnotetext{
${ }^{9}$ W.E. Metcalf, 'Whose Liberalitas? Propaganda and audience in the early Roman Empire', Rivista italiana di numismatica e scienze affini 95 (1993), 337-346. Cf. Noreña 2001, op.cit (n. 6), 160-164 on the quantitative representation of liberalitas on imperial denarii. Noreña's article is an important step in the use of a quantitative approach in the study of iconography and representation, but as it focuses solely on denarii, it is unfortunately of little use for the present contribution.

${ }^{10} \mathrm{Cf}$. the four different target groups described by Lummel 1991, op. cit. (n. 6), 8: senate; armies; plebs urbana; provinces.

${ }^{11}$ Claudius: dupondii: RIC $1^{2}, 127$ no. $94 ; 129$ no. 110 . Nero: sestertii: RIC $1^{2}, 159$ nos. $98-99,161$ nos. $137-142,173$ no. 372,174 no. $389-393,177$ nos. $430-431,180$ nos. $493-497,183$ nos. 566-573. But cf. aurei: RIC $1^{2}, 151$ no. 23,152 nos. 29 and 35. Galba: asses: RIC $1^{2}, 246$ nos. 291-292, 248 nos. 324-326, 251 nos. 420-421. Vitellius: sestertii: RIC $1^{2}, 275$ nos. 131-132 and 144-145, 276 no. 155, 277 no. 166. Vespasian: aurei: BMCRE 2, 48 no. $274 \dagger, 51$ nos. 290-297, 52 nos. 298-300, 93 no. $445 \dagger, 97$ no. 465 ; denarii: nos. 52 no. 301, 92 no. 422,93 no. 445ł; sestertii: BMCRE 2, 166 no.
} 
the congiarium, recipients of which were strictly limited to the plebs frumentaria, was celebrated on high-value coins in the reigns of Trajan, Antoninus Pius and Septimius Severus, though Nero, Titus and Nerva used the legend only on sestertii. ${ }^{12}$ Such lack of consistent differentiation of messages on coins of different values over an extended period of time need not, however, imply absolute absence of audience targeting within individual reigns.

Jones formulated his criticism of the term 'propaganda' largely as a negative reaction to the use of modern preconceptions in analysing the Roman world. It is, thus, highly unlikely that he would be convinced by a response that uses modern parallels as a framework. Still, it is such a framework that I will put forward as a possible way ahead. It follows from the notions that are concerned with the marketing of so-called 'brands': e.g. Coca Cola, Levi's, Virgin, or - with more classical connotations - Mars and Nike. Those brands, after all, try to do what emperors, in their way, were equally aiming for: to create a good name for themselves, for now and posterity, in an empire where most of the inhabitants would never physically see their ruler. Some citations from modern 'rulers' may exemplify the point. Richard Branson, founder of Virgin, has stated how one should 'build brands not around products but around reputation', ${ }^{13}$ whilst Phil Knights, CEO of Nike, pointed out in 1992 that he finally understood 'that the most important thing we do is market the product.${ }^{14}$ Hector Liang, former chairman of United Biscuits, put it rather more bluntly: 'Machines wear out. People die. But

$715 \S, 172$ nos. 730-731. Titus: aurei: BMCRE 2, 224 no. 6, 54-55 nos. 316-323; denarii: BMCRE 2 , 225 no. 7; sestertii: 224 nos. 152-155, 294 no. 307*. Domitian: sestertii: BMCRE 2, 365 nos. 304-305, 368 nos. $323-324,380$ no. 371 ; dupondii: 360 no. $286^{*}, 373$ no. 347,379 no. $368 \ddagger, 382$ no. $381^{*}, 389$ no. 410\$; asses: 391 no. 415; quadrantes: BMCRE 2, 379 no. 370,410 nos. 492-493. Nerva: sestertii: BMCRE 3, 14 no. $85 \dagger, 17$ no. $96 \dagger, 19$ no.101. Trajan: aurei: BMCRE 3, 57 no. 174,96 no. 468 ; denarii: BMCRE 3, 56 nos. 169-172; sestertii: 165-166, nos. 781-784, 183 no. 869, 203 no. 959†, 207 nos. 972-973; dupondii: BMCRE 3, 187 nos. 885-886, 194 no. 918,197 no. 927, 202 no. 959*, 211 no. 996. Hadrian: denarii: BMCRE 3, 288-289 nos. 379 -390, 300 nos. 488-489; sestertii: 479 nos. 1574-1582; dupondii: 437 no. 1334 a, 439 nos. 1346-1347.

${ }^{12}$ Nero: RIC $1^{2}, 159$ nos. $100-102,161-162$ nos. $151-162,177$ nos. $434-435,175$ no. 394,180 nos. 504-506, 183 no. 576. Titus: BMCRE 2, 139 no. 629, and 263. Nerva: BMCRE 3, 14 no. 87, 17 no. 97. Trajan: sestertii: BMCRE 3, 147 no. 712, 161-162 nos. 768-770. Trajan: aureus: G. Spinola, Il 'congiarium' in età imperiale. Aspetti iconografici e topografici (Roma 1990), tav. XII, fig. 38.8. Antoninus Pius: denarii: BMCRE 4, 150 no. 1004; sestertii: 361 no. 2108,362 no. 2111. Septimius Severus: aureus: Spinola, op. cit., tav. XIII figs. 55-56.

${ }^{13}$ N. Klein, No Logo (London 2000), 24.

${ }^{14}$ Harvard Business Review (July 1992), 92; Klein 2000, op. cit. (n. 13), 22. 
what lives on are the brands' ${ }^{15}$ Like Roman emperors, brands manage to survive because of what relevant people think of them. Canon camera commercials of the early 1990s sum it up: 'Image is everything'. ${ }^{16}$ Whilst artefacts are being produced at an undefined level - be they imperial portraits, or jeans - 'Headquarters ... is free to focus on the real business at hand - creating a corporate [or imperial] mythology powerful enough to infuse meaning into these raw objects just by signing its name'. ${ }^{17}$ Such a 'mythology', through advertisements that contain 'preferred meanings', ends up representing reality, rather than just reflecting it. ${ }^{18}$

These advertisements are not consistent over long periods - they change with the changes in dominant consumer groups. When in the 1990's the number of teenagers with large spending power started to increase, brand names tried to become 'cool'; with new messages in new media such as MTV, whilst retaining some of their old advertisements in more conservative media so as not alienate current consumers. ${ }^{19}$ Britain's 'New Labour' does very much the same, and Italy's Silvio Berlusconi has obviously realised how important it is to occupy all forms of broadcasting, to reach all possible audiences, with different messages, whether they want them or not. Also, at a more academic level, one can still see how 'audience targeting' should always be analysed in very specific contexts. For reasons not entirely clear to me, but most probably connected to creating a specific image (and boosting sales figures), Antony Barrett's excellent biography of Agrippina was published, in the same year (1996), under different titles in the UK and US. In Britain, the book is called Agrippina, Sister of Caligula, Wife of Claudius, Mother of Nero. In the States, the same work was issued as Agrippina: Sex, Power and Politics in the Early Roman Empire.

What follows from this, and what might make it relevant as a model for an analysis of Roman imperial coinage, is that one should be aware of particular messages that a broadcaster would want to convey to particular groups at specific moments. When circumstances change, advertisers start to target different groups in different ways. Would Roman emperors not try to do the

\footnotetext{
${ }^{15}$ Irish Times (27-2'98); Klein 2000, op. cit. (n. 13), 196.

${ }^{16}$ Klein 2000, op. cit. (n. 13), 197.

${ }^{17}$ Klein 2000 , op. cit. (n. 13), 21

18 N. Abercrombie \& B. Longhurst, Audiences. A Sociological Theory of Performance and Imagination (London 1998), 11 and 14.

${ }^{19}$ Klein 2000, op. cit. (n. 13), 118-21.
} 
same? Rather than looking at overall patterns, therefore, it may be much more worth while to look at a more closely defined period, in a shorter time span, to see whether at least there denominations did matter.

The Civil War of $\mathrm{AD} 68-69$, a period of great turmoil, forms an interesting test case. It is in such moments of transition that messages become more forceful. As Wallace-Hadrill phrased it: 'liveliness on coins reflects political instability' ${ }^{20}$ Similarly, I would argue, moments in which one needs specific layers of society as power bases are going to be the moments in which targeting those layers is of prime importance. Galba's coins seem to illustrate the point. His gold and silver types refer explicitly to the importance of his provincial support - CONCORDIA PROVINCIARUM figured along Gallia HisPaNia, HisPania, and SALUS GENERIS HUMANI. ${ }^{21}$ The latter seems to have been a specifically anti-Neronian statement in the Western provinces, which had already been used by Vindex. ${ }^{22}$ Coins of lower denomination on the other hand, aimed at the urban plebs of Rome, displayed more urban themes. ${ }^{23}$ Again, this is not to say that none of the urban plebs would ever see coins of higher denomination, or that none of the soldiers would use smaller change. But one can assume a difference of primary audience - and the different types of legends on the different types of coins mirror that.

Otho did not even bother to strike bronze coinage. Partly, this must have been because the flood of small change produced by Nero and Galba was enough for economic needs. ${ }^{24}$ But it coincides markedly with an emperor who tried to indulge the praetorians, and simultaneously win over the senate by following a strict constitutionalist line - as is showed, for

\footnotetext{
${ }^{20}$ Wallace-Hadrill 1986, op. cit. (n. 6), 70.

${ }^{21} \mathrm{RIC}^{2}$, 222. CONCORDIA PROVINCIARUM: aurei: RIC $1^{2}$, 237 no. 104, 238 nos. 117-120; denarii: RIC $1^{2}, 234$ nos. 35 and 49, 235 no. 54, 238 nos. 105-108, 125-126, 241 no. 149, 241-242 nos. 180183. Gallia HisPania: denarii: RIC $1^{2}, 233$ nos. 15-18, 238 no. 109, 241 no. 154. Hispania: aurei: RIC $1^{2}, 242$ no. 192, 243 no. 225; denarii: RIC $1^{2}, 240$ no. 146, 232 nos. 1-3, 233 nos. 19-21, 234 no. 50, 237 no. 86, 240 no. 144, 241 no. 155, 242 nos. 190-191 and 193. SAlus GeNeris HuMANI: aurei: RIC $1^{2}, 240$ no. 146, 242 nos. 206, 208 and 212-213, 243 no. 231; denarii: RIC $1^{2}, 237$ nos. 96-97, 241 nos. 171-172, 242 nos. 205, 207, 209-211 and 214, 243 no. 232. Cf. Gallia: denarii: RIC $1^{2}, 236$ no. 85, and TRES GALLIAE: denarii: RIC $1^{2}, 237$ nos. 89-92.

${ }^{22}$ C.M. Kraay, 'The coinage of Vindex and Galba, $\mathrm{AD} \mathrm{68}$, and the continuity of the Augustan Principate', Numismatic Chronicle $6^{\text {th }}$ series 9 (1949), 129-149; 137-138; Suetonius, Galba 9.2; Tacitus, Histories 1.30. Cf. also ILS 3827, an altar dedicted to Salus Generis Humani that was found near Le Puy and may date from the same years.

${ }^{23}$ Supra $\mathrm{n} .10$ for Ceres and AnNona. Also: SeCuRitas P. Romani SC (asses: RIC 12 255 nos. 491 495) and VICTORIA IMPERI ROMANI (sestertii: RIC $1^{2}, 255$ no. 490).

${ }^{24} \mathrm{RIC} 1^{2}, 258$.
} 
instance by Tacitus, Histories, 1.77. Otho, it appears, limited his primary messages to those who mattered most to him in the nearest future. ${ }^{25}$ Vitellius, on the other hand, issued all denominations, and the differences in legends are noticeable. Gold and silver coins read, among others, CONCORDIA P(OPULI) R(OMANI), CONCORDIA PRAETORIANORUM, PONT(IFEX) MAXIM(US) and XV VIR(I) SACR(IS) FAC(IUNDIS). All of these legends are absent from the bronzes, which instead mentioned themes such as ANNONA AUGUSTI, Ceres Augusti, Pax Augusti and Roma Renascens. Furthermore, the legends on the low-value coins in Rome were much more diversified than those in Spain and Gaul. Was Vitellius perhaps trying to reach especially the Roman plebs? ${ }^{26}$ In any case, the different legends broadcast, quite clearly, different messages for different audiences.

Finally, in the same year, Vespasian is depicted on a rare type with a radiate crown - as a victorious general. The surviving coins are an aureus and a denarius, now in Paris and London ${ }^{27}$ The denarius explicitly relates Vespasian's radiate image to the EXERCITUS MOESIC(US), whereas the Paris aureus has as reverse legend VICT(ORIA) AUG(USTI). The importance for Vespasian of the Moesian legions is clear. ${ }^{28}$ It is possible that these two samples survive from locally issued donatives. ${ }^{29}$ But in this context it is worth stressing the difference between the portrait of the radiated general that seems relevant to the troops, and the veristic old man, who would be so noticeable in later (non-military) portraiture.

While there was a war waging, it seems that specific support groups received different messages. Are similar patterns also discernable for other periods in which struggles for power took place without a war going on? The reign of the emperor Claudius forms an interesting test case. Claudius was not an emperor who is known for his strong power base, whether he was found cowering behind curtains or not. Indeed, the precious metal coinage from the

\footnotetext{
${ }^{25}$ C.L. Murison, Galba, Otho and Vitellius: Careers and Controversies (Hildesheim 1993); E. Keitel, 'Plutarch's Tragedy Tyrants: Galba and Otho', in: R. Brock \& A.J. Woodman, eds., Papers of the Leeds International Latin Seminar 8, Roman Comedy, Augustan Poetry, Historiography (Leeds 1995), 275-288. Cf. Tacitus, Annals 1.78 on Otho's undecided behaviour (ipse in suspenso tenuit) towards the name on Nero, popular among the people of Rome and the lower ranks of soldiers.

${ }^{26}$ See infra, appendices 1 and 2 .

${ }^{27}$ BMCRE 2, lxviii and fig. 19.13; H. Mattingly, British Museum Quarterly 12 (1937/8), 5 fig. 6.12; M. Bergmann, Die Strahlen der Herrscher. Theomorphes Herrscherbild und politische Symbolik im Hellenismus und in der römischen Kaiserzeit (Mainz 1998), Taf. 43, 7-8.

${ }^{28}$ E.g. Tacitus, Annals 2.85; B. Levick, Vespasian (London - New York 1999), 59-60.

${ }^{29}$ Bergmann, 1998, op. cit. (n. 27), 235.
} 
first years of his reign clearly shows which group had got him to power: PRAETOR(IANUS) RECEPT(US), showing the emperor on the left, being greeted by a member of the praetorians. ${ }^{30}$ The image seemingly conveys the message that the emperor only rules through the actions of the praetorians. A similar message follows from aurei and denarii mentioning IMP(ERATOR) RECEPT(US), and showing the castra praetoria with its goddess. ${ }^{31}$

It is clear, and long recognised, that these legends aimed to show Claudius' gratitude to the praetorians, who helped him come to power ${ }^{32}$ Yet, it is noticeable that references to the praetorians are wholly absent from coins of lesser value. On these coins, rather, ANNONA and CERES were emphasised - perhaps not coincidental considering the harbour at Ostia that Claudius constructed from 42 to $46 \mathrm{AD} .^{33}$ The praetorians were celebrated on gold and silver coins that may well have formed the "prime medium of military pay' ${ }^{34}$ On these coins, the absence of popular plebeian messages is noticeable. From $46 \mathrm{AD}$ onwards, the PRAETOR(IANUS) RECEPT(US) legend disappears altogether, whereas two new types suddenly appear on high-value coins. One reads DE BRITANN(IS), whereas the other has as legend S(ENAtus) P(opulus)Q(UE) R(OMANUS) P(ATER) P(ATRiae) OB C(IVEs) S(ERVATOS). After $47 / 8$, there are no longer references to the praetorians at all on Claudius' coinage, whereas the two more recent coin types continue. The legends and iconography on semis, sestertii and dupondii, on the other hand, did not change at all in these years.

Had Claudius, perhaps, become less dependent on the praetorians? He had brought some projects that were aimed at the populace at large to a successful end, and had survived senatorial uprisings. Perhaps he no longer

\footnotetext{
${ }^{30} \mathrm{RIC} 1^{2}, 122$ nos. 11-12 and 23-24, 123 no. 29. Cf. M. von Kaenel, Münzprägung und Münzbildnis des Claudius (Berlin 1986).

${ }^{31}$ RIC $1^{2}, 122$ nos. 19, 20 and 25-26, 123 nos. 36-37; A. Alföldi, Die monarchische Repräsentation im römischen Kaiserreiche $\left(1980^{3}\right)$, 215; Lummel 1991, op. cit. (n. 6), 58-59.

${ }^{32}$ Th. Wiedemann, The Julio-Claudian Emperors. AD 14-70 (Bristol 1989), 44-45; B. Levick, Claudius (London 1990), 39; Lummel 1991, op. cit. (n. 6), 58-59.

${ }^{33} \mathrm{Cf}$. supra $\mathrm{n} .10$. On the harbour, and its celebration in coinage, see Levick 1990, op. cit. (n. 32), 110, 219 notes 17-18 with references; M. R.-Alföldi, 'Die Bildersprache der römischen Kaiser', Numismatica e antichità classiche 30 (2001), 209-227; 222-223.

${ }^{34}$ RIC $1^{2}, 222$; M. Hassall, 'The army', CAH $11^{2}$ (2000), 320-343; 330. Cf. B. Campbell, The Emperor and the Roman Army (Oxford 1984), 167; Von Kaenel 1986, op. cit. (n. 30), 259-261. Soldiers did, however, also use bronzes, which have been found in large numbers at excavations of military camps. It is simply not known how Roman soldiers were paid, but with a legionary centurion being paid around 13,500 sestertii under Augustus, and 108,000 sestertii under Maximinus Thrax (M.A. Speidel, 'Roman Army Pay Scales', Joumal of Roman Studies 82 [1992], 87-106; 102, 106), it seems clear that at least silver coinage must have been regularly used.
} 
felt he needed the praetorians as much as he had previously done. Whatever the reason - there seems to have been a change in the message on the coins of higher denomination, whereas the less valuable coins sent out a continuous, though separated, message.

Similarly, the context of Nero's reign, and the development in that emperor's representation over the years may explain some changes in coins of different denominations. Thus, the beginning of his reign saw, among other things, a temporary arrival of the legend EX S(ENATUS) C(ONSULTO) on the gold and silver coinage. Is this the senate celebrating amongst themselves about their regained influence, or a message from the princeps to the upper levels of society that he, more than his predecessors, would take the senate seriously? We cannot tell. But the legend is limited to coins of high denomination, and disappeared from aurei and denarii in $\mathrm{AD} 64$ never to reappear. ${ }^{35}$ In the same year, the building of the Domus Aurea started, and the Colossus was planned ${ }^{36}$ Also, of course, Seneca lost his power. A year later, he was forced to commit suicide. ${ }^{37}$ It seems clear that AD 64/5 marks a break in Neronian self-presentation: a break away from appeasing the senators, and towards pleasing the 'people'. ${ }^{38}$

It is, in this light, worth noting that some typical 'popular' buildings, such as the harbour at Ostia and the Macellum were only depicted on lowvalue coins. ${ }^{39}$

More examples of coins of different values consistently broadcasting different messages within individual reigns are of course needed. Ideally, one would like a structural analysis of the different legends and figures on different denominations in individual reigns - with attention to dates and the political-historical context in which coins were issued. That, of course, far exceeds the scope this article - if it is manageable at all. But it seems clear that looking at possible 'audience-targeting' with the needs and possibilities

\footnotetext{
${ }^{35}$ M. Griffin, Nero. The End of a Dynasty (London 1984), 122.

${ }^{36}$ Cf. Griffin 1984, op. cit. (n.35), 121-122. See now on the Domus Aurea the articles by E.M. Moormann and Y. Perrin in this volume.

${ }^{37}$ M. Griffin, Seneca. A Philosopher in Politics (Oxford 1976), 367-368.

${ }^{38}$ Cf. N. Hannestad, 'Nero and the potentialities of the emperor', in: N.Boncasa \& G.Rizza, eds., Ritratto ufficiale e ritratto privato. Atti del II Conferenza Internazionale sul ritratto Romano (Rome 1988), 325-329; J. Elsner \& J. Master, eds., Reflections of Nero. Culture, History \& Representation (London 1994).

${ }^{39}$ The harbour at Ostia: sestertii: RIC $1^{2}, 162$ nos. $178-183,181$ nos. 513-514; Macellum: sestertii: RIC $1^{2}, 162-163$ nos. 184-189; dupondii: 159 nos. 109-111, 175 nos. 399-402.
} 
of the individual emperor in mind makes sense. Thus, rather than emphasising how, under Titus, CERES and ANNONA were displayed on aurei, and that therefore there is no consistent differentiation in messages on coins of higher or lower value, one could stress that the Flavians had another, perhaps more important, symbol to emphasise to the Roman plebs: the Colosseum. Just to note, all representations of the Colosseum on imperial coinage are on low value coins. ${ }^{40}$

The awareness of 'audience targeting' through coins may even have been more sophisticated. Perhaps the possibility of using ambiguous abbreviations was employed as well. Some Romans were aware of such ambiguity, occasionally even intended:

"Tullius Tiro, Cicero's freedman, wrote at great length in one of his letters, substantially as follows: 'When Pompey was preparing to consecrate the temple of Victory, the steps of which formed his theatre, and to inscribe upon it his names and honours, the question arose whether consul tertium should be written, or tertio. Pompey took great pains to refer this question to the most learned men of Rome, and when there was difference of opinion ... Pompey asked Cicero ... to decide upon what seemed to him the most correct form". Then Cicero was reluctant to pass judgement upon learned men, lest he might seem to have censured the men themselves in criticising their opinion. "He accordingly advised Pompey to write neither tertium or tertio, but to inscribe the four letters only, so that the meaning was shown without writing the whole word, but yet the doubt as to the form of the word was concealed'.."41

\footnotetext{
${ }^{40}$ BMCRE 2, 170 nos. 445-446, 262, nos. 190-191; Lummel 1991, op. cit. (n. 6), 76, 93 and $177 \mathrm{n}$ 575; H. Küthmann et.al., eds., Bauten Roms auf Münzen und Medaillen (Munich 1973), 52ff.; M.R Alföldi 2001, op. cit. (n. 33), 221; Lummel 1991, op. cit. (n. 6), 24, 27 and 93. Limitations of size (cf. supra, note 9, Metcalf) need not have been the reason for this, since detailed depictions of - for example - Trajan's column feature also on the (smaller) coins of high denominations.

${ }^{41}$ Aulus Gellius, Attic Nights 10.1.7: Tiro Tullius, Ciceronis libertus, in epistula quadam enarratius scripsit ad hunc ferme modum: "Cum Pompeius" inquit "aedem Victoriae dedicaturus foret, cuius gradus vicem theatri essent, nomenque eius et honores inscriberentur, quaeri coeptum est, utrum consul tertio inscribendum esset an tertium. Eam rem Pompeius exquisitissime rettulit ad doctissimos civitatis, cumque dissentiretur ... rogavit ... Ciceronem Pompeius, ut, quod ei rectius videretur, scribi iuberet". Tum Ciceronem iudicare de viris doctis veritum esse, ne, quorum opinionem inprobasset, ipsos videretur inprobasse. "Persuasit igitur Pompeio, ut neque tertium neque tertio scriberetur, sed
} 
Were abbreviations also used purposefully in designing coin-legends? This may well be the case. An example is formed by some coins of the usurper Carausius (AD 286-93). ${ }^{42}$ On his silver coinage, the exergue marks RSR and I.N.P.C.D.A have long been puzzling, but, in a recent article, Guy de la Bédoyère has put forward an interesting theory. ${ }^{43}$ He notes how another coin type of Carausius reads EXPECTATE VENI and relates this to Virgil, Aeneid, 2.283 , where, too, a long awaited one was to arrive. ${ }^{44}$ With that in mind, it becomes noticeable how the two exergue marks stunningly follow Virgil's Eclogues 4.6-7: redeunt Saturnia regna. Iam nova progenies caelo demittitur alto. Virgil's passage also connects well with Carausius' emphasis on Rome reborn; a concept that was emphasised through legends that celebrated Carausius as the RENOVAT(OR) ROMAN(ORUM). ${ }^{45}$ If this argument is right, only those with a very high degree of literacy could have understood the point. It is, thus, hardly surprising that these complicated legends only appeared on coins of higher denomination. Carausius aimed his message solely 'at least to those who mattered'. ${ }^{46}$

Perhaps an earlier example of conscious use of ambiguous abbreviation can already be found in the reign of Commodus. In AD 190 or 191, whilst the emperor Commodus was busily reinventing his selfrepresentation by invoking the Hercules Commodiamus, and becoming the Hercules Romanus, a rare aureus was issued. ${ }^{47}$ The iconography on the reverse was the same as the one of a new coin-type that was issued in sesterces, dupondii, and asses. It showed Hercules, naked to the waist, sacrificing over a lighted altar, holding cornocupiae, whilst his club, lion skin, and quiver were resting against a tree. But whereas the legends of all the issues of smaller denominations mention HERCULI COMMODIANO, the aureus reads HERC COM. The difference in size between the aureus and the asses is, in this case, not

ad secundum usque t fierent litterae, ut verbo non perscripto res quidem demonstraretur, sed dictio tamen ambigua verbi lateret". This passage was kindly brought to my attention by Cliff Ando.

${ }^{42}$ On Carausius: P.J. Casey, Carausius and Allectus. The British Usurpers (London 1994).

${ }^{43}$ BM 1900-11-5-10, RIC 5.2, 510, nos. 554-558; G. de la Bédoyère, 'Carausius and the marks RSR and I. N. P. C. D. A', Numismatic Chronicle 158 (1998), 79-88.

${ }^{44}$ De la Bédoyère 1998, op. cit. (n. 43), 82.

${ }^{45}$ RIC 5.2, 571

${ }^{46}$ De la Bédoyère 1998, op. cit. (n. 43), 88.

${ }^{47}$ RIC 3, no. 221 (= BMCRE 4, no. 300). On Commodus' self-representation, and the role of Hercules in it, see: O.J. Hekster, Commodus. An Emperor at the Crossroads (Amsterdam 2002), 87-162 (87-111 for coinage); idem, 'Commodus-Hercules: the people's princeps', Scripta Classica Israelica 20 (2001), 51-83. 
very great, so lack of space on the gold coin need not have been the reason for the abbreviation. ${ }^{48}$ Is this, perhaps, an occasion of 'audience-control'? Rather than unequivocally imposing the Hercules Commodianus on those who would come to see the gold coin, a more ambiguous abbreviation was used. ${ }^{49}$ For the legend COM might bring to mind the word comes as well as (and in fact perhaps even better than) Commodianus, as one can see in inscriptions ${ }^{50}$ It is, thus, possible that the most outrageous claims of Commodus' self-presentation were initially introduced on low-value coins, whilst those who saw the aurei (including, in all likelihood, the senatorial elite), were given the possibility to see these claims in a more conventional light. Having Hercules as comes was, after all, perfectly traditional.

There seems, then, to have been some sophistication in the use of abbreviations and legends on coinage, along with an apparent awareness of audiences of particular media in the Roman Empire. ${ }^{51}$ At least in some cases may thus be shown, in answer to Jones, 'at what classes the propaganda on the coins was directed'. ${ }^{2}$ Some more caveats are still necessary - some differences may depend on different mints, and new money would only form a fraction of the types in circulation. ${ }^{53}$ More problematic is the near-absence of

\footnotetext{
${ }^{48}$ Size aureus: RIC 3, no. 221 (= BMCRE 4, no. 300) 20mm.; 7.30g. Cf. as: RIC 3, no. 591 (= BMCRE 4, no. 677): $25 \mathrm{~mm}$; $8.70 \mathrm{~g}$.

${ }^{49}$ If so, it was a temporary measure at most, as later, in $\mathrm{AD}$ 191-192, cities, legions, and even the senate itself was renamed Commodianus, leaving very little space for subtleties. But that need not mean there was never any subtlety in the first place; Hekster 2002, op. cit. (n. 47), 78 (with references) and 105f. Cf. also Concor(DiA) COMmodi(ANA) (BMCRE 4, NOS. 668, 675*) the Flamen Comm(odianus) (CIL 6.1577); the ordo decurionum commodianor(um) (CIL $14.2449=$ ILS 400, addressed to Commodus as Invictus Romanus Hercules), and the FElic(ITAS) Com(MOdiana) (BMCRE 4, p. 746). Cf. EDH no. HD000480 (= AE 1982.958).

${ }^{50}$ COM for comes or comites: EDH nos. HD030150, HD022151, HD008808, HD005966, HD023629, HD018443. COMM for Commodus or Commodianus: EDH nos. HD208836, HD032451. But cf. HD023999, HD013918 for COM abbreviating Commodus.

${ }^{51}$ C. Ando, Imperial Ideology and Provincial Loyalty in the Roman Empire (2000), argues in a similar vein when discussing Vitellius' use of V. AuG. on his coins. Vitellius' message 'at once acknowledged and legitimated the transfer of charismatic power from Augustus and his family to the office that he had created. In this process the use of Augustus as a title, and the ambiguity inherent in Latin abbreviations can only have smoothed the way' (p. 294, with n. 73). Cf. J. Gagé, 'Un theme de l'art impérial Romain. La Victoire d'Auguste', Mélanges de l' École Française de Rome, Antiquité, 49 (1932), 61-92.

${ }^{52}$ Cf. supra n. 5.

${ }^{53}$ C. Howgego, 'The supply and use of money in the Roman world', Journal of Roman Studies 82 (1992), 1-31; 12-16; R. Duncan-Jones, Money and Government in the Roman Empire (Cambridge 1994), 172-179. Still, if there is one thing that the introduction of the Euro made clear, it is that people scrutinise new coins much more than old ones. On the different mints, see now: R. Wolters, 'Die Organisation der Münzprägung in julisch-claudischen Zeit', Numismatische Zeitschrift 106/7 (1999), 75-90.
} 
geographical audience targeting. The mint of Lugdunum, for instance, must have supplied coins to the northwestern part of the Empire, but its coin-types regularly follow the Roman mint, depicting monuments that would have appealed to the inhabitants of the city of Rome, but far less so to people in the provinces. ${ }^{54}$ The apparent absence of one obvious form of audience targeting does not, however, invalidate the concept as such. There also remains the problem of who decided on coin-types. ${ }^{55}$ But by-passing that question, and placing a 'black-box' in the centre from which the coins emanated, it is noticeable that coins were not devoid of ideological messages, and that those messages make more sense when one defines the context in which, and the audience for which, they seem to have been intended.

Two final examples, one modern, one ancient, may show how important it can be to keep one's audience in mind, since not doing so might have unexpected consequences. Ernst Gombrich recounted the first one: 'Some years ago there was a story in the papers to the effect that riots had broken out in an underdeveloped country because of rumours that human flesh was being sold in a store. The rumour was being traced to food cans with a grinning boy on the label ... As a rule the picture of fruit, vegetable or meat on a food container does indicate its contents; if we do not draw the conclusion that the same applies to a picture of a human being on the container, it is because we rule out the possibility from the start' ${ }^{56}$ This audience did not rule out that possibility. The message went wrong. Somewhat, though not entirely, comparable, was the reaction of the people of the Roman Empire to Elagabalus' attempts to propagate his stone of Emesa on coins. It was not deemed a proper image for coin-types. Audiences reacted badly. Rather than trying to placate a specific group with a message that would appeal, the image was put forward without realising (or perhaps considering) what the reactions of different audiences would be. Elegabalus' coins did not convince the audience he was dependent on. Other emperors did a better job.

Oxford, September 2002

\footnotetext{
${ }^{54}$ Unless, of course, the coins were meant to emphasise the greatness of Rome.

${ }^{55} \mathrm{Cf}$. Wallace-Hadrill 1986, op. cit. (n. 6), 68, with n.6 for references; Levick 1999, op. cit. (n. 6), 58.

${ }^{56}$ E.H. Gombrich, 'The Visual Image. Its Place in Communication', The Image and the Eye. Further Studies in the Psychology of Pictorial Representation (London 1982), 137-162; 143.
} 


\section{APPENDIX 1: REVERSE LEGENDS OF VITELLIUS ON COINS OF DIFFERENT DENOMINATIONS IN THE PROVINCES ${ }^{57}$}

\section{Exclusively on high denominations}

CONCORDIA PRAETORIANORUM ( $D:$ no. 19$)$

SENAT P Q ROMANUS

(Au: no. 32)

I O MAX CAPITOLINUS

(D: nos. 31, 56)

VESTA P R QUIRTTUM

( $A u$ : no. $58 ; D$ nos. $33,59-60,65$ )

L VITELLI III COS CENSOR

(Au: no. 7)

LIBERI(S) IMP GERMANICI

(Au: no. 8; D: no. 57)

SECURTTAS IMP GERM

(Au: nos. 11-2)

VICTORIA IMP GERMAN(ICI)

(Au: nos. 15-6)

Exclusively on low denominations

ROMA RENASCENS

(no. 45)

CONSENSUS HISPANIARUM

(no. 41)

Both on high and low denominations

VICTORIA AUGUSTI

LIBERTAS RESTTTUA

CONSENSUS EXERCITUUM

FIDES EXERCITUM

ClEMENTIA IMP GERMAN(ICI)
( $A u$ : nos. 13-4, 34-5, 38, 61; D: nos. 36-37, 62-3; as: no. 46)

( $A$ u: no. 9; $D$ : no. 10; as: nos. 43-4)

(Au: nos. 4-5, 22, 26, 50, 64; D: nos. 6, 20-1, 23-5, 49, 51; as: no. 40)

( $A u$ : no. 52; $D$ : nos. 27-30, 47, 53-5; as: no. 42)

(Au: nos. 1-3, 16; D: no. 18; as: no. 39)

${ }^{57}$ All references to RIC I I, $268-71$ 


\title{
APPENDIX 2: REVERSE LEGENDS OF VITELLIUS ON COINS OF DIFFERENT DENOMINATIONS IN ROME ${ }^{58}$
}

\author{
Exclusively on high denominations Exclusively on low denominations ${ }^{59}$ \\ FIDES EXERCITUM ( $D:$ no. 67) \\ ROMA (Dp: no. 130) \\ LIBERI IMP GERMANICI \\ SECURTTAS P ROMANI (as: no. 175) \\ (Au: nos. 78, 104; $D:$ nos. 79, 105) \\ PAX GER ROM (sest: nos. 119-21) \\ LIBERTAS RESTITUA ( $A u$ : no. 80; \\ LIBERTAS AUGUSTI ( $D p$ / as: no. 128) \\ $D:$ nos. 69, 81) \\ IUPPITER VICTOR \\ MARS VICTOR \\ ( $A u$ : nos. 74, 92; D: nos. 68, 75, 93) \\ (sest: nos. 115-6, 136-7, 156, 167-8) \\ L VITELLI III COS CENSOR \\ L VITELLI CENSOR II (sest: nos. 114, 134) \\ L VITELLI CENSOR III (sest: no. 135) \\ ( $A u$ : nos. 76, 94, 96, 98; D: nos. 77, 95, I O MAX CAPITO (as: no. 127) \\ 97, 99) \\ VESTA ( $D p /$ as: no. 154$)$ \\ XVVIR SACR FAC \\ HONOS ET VIRTUS (sest: no. 113) \\ ( $A u$ : nos. 85, 87, 108; $D$ : nos. 70-1, 86, CONCORDIA AUG(USTI) \\ 88, 109) \\ (sest: no. $133 ; D p$ : no. $126 ; D p / a s$ : nos. \\ PONT MAXIM ( $A u$ : no. $106 ; D$ : no. 107$)$ \\ CONCORDIA P R \\ 161-2, 170; as: no. 171) \\ ( $A u$ : nos. 72, 89; $D$ : nos. 66, 73, 90; \\ PAX AUGUSTI \\ $A R Q$ : no. 91) \\ (sest: nos. 117-8, 138-41, 157; Dp: nos. \\ 146-8; Dp/as: nos. 149, 164; as: no. 172) \\ AEQUTTAS AUGUSTI (as: nos. 125, 160) \\ ANNONA AUG \\ (sest: nos. 131, 155, 166; Dp/ as: no. 144) \\ CERES AUG (sest: no. 132; as: no. 145) \\ PROVIDENT (as: nos. 129, 150, 173-4)
}

\author{
Both on high and low denominations \\ VICTORIA AUG(USTI) ( $A u$ : no. $111 ; D$ : no. 112; $A R Q$ : no. 84 ; sest: nos. 124, 142-3; \\ as: nos. 151-2, 156, 176) \\ SPQR OB CS $\quad(A u: \operatorname{nos} .82 ; D:$ nos. 70,$83 ;$ sest: 122,159$)$
}

\footnotetext{
${ }^{58}$ All references to $\mathrm{RIC} \mathrm{I}{ }^{2}, 271-7$

${ }^{59}$ All legends followed by SC.
} 